\title{
Molecular mechanisms of hepatopulmonary syndrome
}

\author{
I.Ya. Krynytska, M.I. Marushchak, I. M. Klishch, I.V. Birchenko \\ I. Horbachevsky Ternopil State Medical University; e-mail: krynytska@tdmu.edu.ua
}

\begin{abstract}
Hepatopulmonary syndrome (HPS) is a severe complication seen in advance liver disease. Its prevalence among cirrhotic patients varies from 4 to 47 percent. HPS exact pathogenesis remains unknown. In this review we summarized existing knowledge on the possible mechanisms and causes of the HPS. Pulmonary microvascular dilation and angiogenesis are two central pathogenic features that drive abnormal pulmonary gas exchange in experimental HPS, and thus might underlie HPS in humans. Despite these insights into the pathogenesis of experimental HPS, there is no established medical therapy, and liver transplantation remains the main treatment.

Key words: hepatopulmonary syndrome; molecular mechanisms.
\end{abstract}

\section{DEFINITION, PREVALENCE AND CLASSIFICATION}

The occurrence of combined liver and lungs pathology was initially described by M. Fluckiger (Austria) in 1884 when he observed cyanosis and clubbed fingers in young woman with liver cirrhosis due to the presence of syphilis [1]. Today the term "hepatopulmonary syndrome" (HPS) describes deficiency of arterial oxygenation caused by dilatation of intrapulmonary vessels associated with liver disease [2-5]. A classification of the severity of HPS based on oxygenation abnormalities has been proposed [4] (table 1).

Non-specific clinical criteria combined with the lack of standartization of HPS diagnostic criteria can lead to diagnostic errors [6]. It also explains the wide range of HPS frequency reported by authors. HPS is diagnosed in 4 to $47 \%$ of patients with cirrhosis and 15 to $20 \%$ of candidates for liver transplant [7-9]. Studies in children have shown that HPS occurs in 9 to $29 \%$ of children with chronic liver disease [10].

\section{PROGNOSIS AND TREATMENT OPTIONS}

Since pathogenesis of HPS is not fully clarified, there is no effective pharmacological therapy and orthotopic liver transplant is the only successful treatment method [11, 12]. Without a liver transplant the prognosis of HPS is poor. If HPS develops, the risk of death in the next year is $41 \%$. This syndrome can be considered as a separate indication for a liver transplant [13-16], but at the same time the severe hypoxia in the case of HPS is associated with a high risk of liver transplant complications (30\% during the first 90 days) and increased gap between the transplant surgery and improvement in arterial oxygenation [17]. This complication is seen in $6-21 \%$ of the patients and carries a $45 \%$ chance of mortality [18].

Table 1. Grading of severity of hepatopulmonary syndrome

\begin{tabular}{lc}
\hline $\begin{array}{l}\text { Mild HPS } \\
\text { Moderate HPS }\end{array}$ & $\mathrm{AaDO}_{2} \geq 15 \mathrm{mmHg}, \mathrm{PaO}_{2} \geq 80 \mathrm{mmHg}$ \\
$\begin{array}{l}\text { Severe форма HPS } \\
\text { Very severe HPS }\end{array}$ & $\mathrm{AaDO}_{2} \geq 15 \mathrm{mmHg}, \mathrm{PaO}_{2} \geq 50-<60 \mathrm{mmHg}$ \\
\hline *AaDO & $\mathrm{AaDO}_{2} \geq 15 \mathrm{mmHg}, \mathrm{PaO}_{2}<50 \mathrm{mmHg}$ \\
(C) I.Ya. Krynytska, M.I. Marushchak, I. M. Klishch, I. Birchenko
\end{tabular}




\section{PATHOPHYSIOLOGY}

Since the basis of HPS pathogenesis is the dilation of inner lung capillaries, researches suggest that HPS is caused by the prolonged action of biologically active compounds on the blood vessels of pulmonary circuit. Possible role in emergence of resistant vasodilation have been suggested for many substances synthesized in the body. Potential mediators of HPS include: nitrogen (II) oxide, endothelin B and endothelin-1, prostaglandins $\mathrm{E}_{1}$ and $\mathrm{I}_{2}$, tumor necrosis factor $-\alpha$, vasoactive intestinal polypeptide, substance $\mathrm{P}$, calcitonin, glucagon, platelets activating factor, and others [19].

\section{NITRIC OXIDE MEDIATED VASODILATION}

Since nitrogen (II) oxide (NO) is recognized as one of the most powerful endogenous pulmonary vasodilators, it has been suggested as the most likely candidate not only for the hyperdynamic type of circulation in liver cirrhosis, but also for HPS [20]. NO is a highly reactive molecule with a half-life of 2 to 30 seconds, formed by the enzymatic oxidation of $\mathrm{L}$-arginine under the influence of cytochrome P450-like hemoproteins, NO-synthases (NOS). There are three isoforms of this enzyme: endothelial (eNOS), neuronal (nNOS) and inducible (iNOS) or macrophagal [21, 22]. As a lipophilic molecule, $\mathrm{NO}$ easily diffuses through cell membranes into the neighbouring cells (e.g. from endothelial to myocytes of vessels) where cyclic guanosine monophosphate decreases concentration of free calcium and activates myosin light chain kinase causing vessel dilatation [23].

A series of experimental studies investigated NO quantities in the context of liver cirrhosis and HPS. Fallon et al. have emphasised the role of NO in experimental models of liver cirrhosis, where overexpression of eNOS by pulmonary vessels causes the increased production of endothelin-1 (ET-1) by cholangiocytes, resulting in increased expression of endothelin receptor type B to ET-1 at the level of pulmonary vessels, and increases synthesis of nitrogen (II) oxide [24].

The level of NO in exhaled air was elevated in patients with HPS, returning to normal 3 to 12 months after the liver transplant $[25,26]$. In a similar study, Degano et al. found that concentration of NO in exhaled air of patients with cirrhosis was three times higher than that in healthy persons [27]. Using flow cytometry, which allowed to differentiate alveolar and bronchial origin of $\mathrm{NO}$, it was determined that the increased formation of $\mathrm{NO}$ mainly took place in the alveoli [28]. Notably, the production of nitrogen (II) oxide by alveoli can play an important role in haemodynamic disturbances and changes in gas exchange in patients with cirrhosis. Thus, a direct corellation between the alveolar production of $\mathrm{NO}$ and hyperdynamic type of circulation was established [27]. Moreover, overexpression of both inducible and constitutional isoforms of NO-synthase in alveolar macrophages and pulmonary endothelial cells was observed in rats with experimental liver cirrhosis $[29,30]$. While this pulmonary overexpression has not yet been found in patients with HPS, it probably occurs in most cases of HPS, at least in patients who have been successfully treated using inhibitors of nitrogen (II) oxide synthesis or its targets, so-called secondary messengers of cyclic guanosine monophosphate.

Several studies have successfully used the following therapeutic approaches in patients with HPS: either intravenous introduction of methylene blue, which is the main inhibitor of NO molecular target, cyclic guanosine monophosphate or spraying with NO synthase inhibitor (N-nitro-L-arginine methyl ester) [31-33]. However, further studies showed, that NO concentration does not affect hyperdynamic circulation and the severity of liver damage in cirrhosis patients. Thus, methylene blue has improved arterial oxygenation, but only temporarily, while L-NAME had no effect on gas exchange in many patients with HPS [34]. 


\section{TUMOR NECROSIS FACTOR- $\alpha$}

There is evidence that in liver cirrhosis patients the level of tumor necrosis factor- $\alpha$ increases, playing an important role in the accumulation of macrophages in the lumen of the pulmonary vessels. In turn, these macrophages encourage other NO-producing enzyme, inducible NO-synthase, thus likely causing pulmonary vasodilation [24]. However, other studies have found that while the level of circulating TNF- $\alpha$ was significantly increased in thioacetamide-induced liver cirrhosis, the accumulation of macrophages in the lumen of pulmonary vessels was minimal and HPS didnot develop [35]. Studies suggest, that neutralization of tumor necrosis factor $-\alpha$ improve the course of experimental HPS [36].

TNF- $\alpha$ (cachectin) is a polypeptide cytokine, a major initiator of many pathophysiological responses of the body. Structurally it is a homotrymer, exhibiting biological activity after binding to specific membrane receptors, TNF $\alpha \mathrm{R} 1$ (gp 55, CD 120a) and TNF $\alpha-R 2$ (gp 75, CD $120 \mathrm{~b})$, which differ in their expression pattern, downstream signal-transduction cascades, and binding affinity for $\mathrm{TNF}-\alpha$ [37]. Interaction of $\mathrm{TNF}-\alpha$ with receptors leads to activation of transcription factors, which regulate genes of a wide range of mediators, such as IL-1, IL-6, IL-8, prostaglandins, platelet- activating factor, platelet-derived growth factor, and hormones (epinephrine).

The cytoplasmic tail of TNFR1 contains a death domain; however, this motif is missing in TNFR2. Although it was initially thought that TNFR1 activation was involved in the cytotoxic and apoptotic effects of $\mathrm{TNF}-\alpha$, while those related to cell survival and proliferation involved TNFR2 activation, now it is becoming clear that TNFR2 can also induce cell death. Inside the cell, signal is transmitted through a complex system of proteins to the factors that control transcription: nuclear factor $\mathrm{kB}(\mathrm{NF}-\mathrm{kB})$ and c-Jun [37].

The main producers of $\mathrm{TNF}-\alpha$ are monocytes and macrophages, but there are also oth- ers: blood lymphocytes, natural killer cells, granulocytes, and $\mathrm{T}$ lymphocytes. The principal inducers of TNF- $\alpha$ synthesis are bacterial lipopolysaccharides and other components of microorganisms [38]. TNF- $\alpha$ induces cytotoxic effects on endothelial cells, enhances the adhesion of neutrophils to them by increasing the production of chemokines and adhesion molecules, increases vascular permeability directly through the activation of neutrophils, and enhances angiogenesis [39]. With its ability to activate apoptosis, TNF- $\alpha$ also causes activation of reactive oxygen species and NO in the cell membrane. In the study of animals with HPS, Sztrymf et al. achieved reduction of TNF- $\alpha$ in the blood using $10 \mathrm{mg} / \mathrm{kg}$ of pentoxifylline. Pentoxifylline prevented NO synthase activation in the aorta and pulmonary artery [40].

\section{CARBON MONOXIDE AND HYDROGEN SULFIDE MEDIATED VASODILATION}

In addition, other molecular mechanisms of nitric oxide-independent vasodilation are discussed in the literature, such as enzymatic formation of $\mathrm{CO}$ by increased expression of heam oxygenase-1 enzymatic formation of $\mathrm{H}_{2} \mathrm{~S}$, and stimulation of calcium-activated potassium channels by endothelium-derived hyperpolarization factor $[38,41]$. CO is a gaseous molecule that can be synthesised in at least two distinct pathways. The main pathway is catalized by haem oxygenase degradation of haem. The secondary mechanism, involves chemical reactions such as oxidation of certain organic molecules, including salts, alkyl radicals as well as autoxidation, and lipid peroxidation of cell membranes. Activating soluble guanylate cyclase, $\mathrm{CO}$ promotes the production of cyclic guanosine monophosphate, which causes relaxation of smooth muscle cells of blood vessels.

There are three isoforms of haem oxyganase: HO-1, HO-2 and HO-3. HO-1 is inducible, while $\mathrm{HO}-2$ and $\mathrm{HO}_{-} 3$ are stable in cells. $\mathrm{HO}_{-}-1$, also known as heat shock protein, is mainly located in the liver, spleen, reticuloendothelial system 
and bone marrow. Its activity is stimulated by cellular stress [41]. HO-2 and $\mathrm{HO}-3$ can be found in various parts of the body; however, HO-2 is mainly detected in the brain, and blood vessels, while HO-3 is found in the spleen, liver, heart, kidneys, and brain. Reports indicate that in liver cirrhosis patients with HPS due to, the level of HO-1 in pulmonary intravascular macrophages is increased and this is complemented with increased $\mathrm{CO}$ production [42]. Existing reverse relationship between partial pressure of oxygen and carboxyhaemglobin concentration in patients with HPS point to a potential impact of increased $\mathrm{CO}$ formation on abnormal gas exchange. In addition, Van Landeghem et al. have observed that zinc protoporphyrin, an HO-1 inhibitor causes normalization of carboxyhaemglobin levels in arterial blood, decrease of pulmonary vasodilation and improvement of HPS symptoms [42]. These studies support the hypothesis that $\mathrm{HO}-1 / \mathrm{CO}$ system plays an important role in the pathogenesis of HPS.

Hydrogen sulfide $\left(\mathrm{H}_{2} \mathrm{~S}\right)$ is produced in all tissues, particularly in vascular endothelium [43]. $\mathrm{H}_{2} \mathrm{~S}$ synthesis from homocysteine is catalyzed solely by cystationine- $\beta$-synthase, whereas its synthesis from cysteine is catalyzed by several enzymes: cysteine aminotransferase, cystationine- $\gamma$-lyase and cystationine- $\beta-$ synthase. Hydrogen sulfide can also be synthesized by the reduction of thiosulfate by thiosulfate disulfide transferase. $\mathrm{H}_{2} \mathrm{~S}$ is involved in numerous reactions, including binding with $\mathrm{SH}$-groups of proteins and low molecular weight thiols, modifying their activity, interacting with sulfite anion, and forming thiosulfate. It can also be methylated by thiol methyltransferase, producing methane thiol. Additionally, hydrogen sulfide can produce nitrozotiols and nonenzymatically oxidate to sulfites and sulfates [44-46]. It is recognized that $\mathrm{H}_{2} \mathrm{~S}$ plays a significant role in the regulation of vascular tone, inducing vazodilation, as well as in platelet aggregation, myocardial contractility, neurotransmission, and secretion of insulin [41, 47, 48].

Vascular tone is also regulated by ATP-sen- sitive $\mathrm{K}^{+}$channels $\left(\mathrm{K}_{\mathrm{ATP}}\right.$ channels). They open in vascular smooth muscle cells, causing hyperpolarization and subsequent vasorelaxation [41]. The experiments with $\mathrm{K}_{\text {ATP }}$ channel modulators in mesentery of rats with simulated secondary biliary cirrhosis have demonstrated that the channels are mostly open in dilated vessels [49]. In addition, $\mathrm{K}_{\mathrm{ATP}}$ channels are the targets for $\mathrm{H}_{2} \mathrm{~S}$. The chemical identity of hyperpolarization factor have not yet been determined, however, some candidate compounds for its induced vasodilation action are proposed, including monovalent cations of potassium, metabolites of arachidonic acid, and hydrogen peroxide. The action of hyperpolarization factor is the most prominent in small arteries and arterioles [41].

Simultanoeus to the increased production in endothelium of locally acting vasodilators, endothelium-independent hyposensitivity to circulating endogenous vasoconstrictors also causes the decrease of vascular tone [41]. A large number of studies on isolated perfusated mesenteric arteries and aorta of rats with various models of portal hypertension showed that decreased vasoconstrictor response to $\alpha_{1}$-adrenoceptors agonists (phenylephrine, metoksamin, norepinephrine), angiotensin II and vasopressin which persisted even after the removal of endothelium or pharmacological inhibition of endogenous NO production [50]. This hypocontractility can be due to malfunctioning vascular RhoA/Rho kinase signalling or disrupted response to angiotensin II as a result of increased expression of the receptor to $G$ protein-bound protein kinase 2 and protein $\beta$-arestyne 2 bound to angiotensin II receptor type 1 [51, 52].

Another hypothesis stipulates that angiotensin II is major etiological factor in HPS pathogenesis [19]. According to this theory, HPS symptoms develop as a result vascular dilatation associated with abnormal reactivity to angiotensin II (reduction of vasoconstrictor effect) and with simultaneous increase of NO concentration, a potent vasodilator. In experiments on rats Castro et al. showed that the vasoconstrictor effect of angiotensin may be restored by inhibiting of 
NO [53]. Chang et al. observed in animal models that intravenous infusion of angiotensin II can partially restore disrupted constrictor ability of pulmonary vessels [54]. However, the current state of knowledge about the role of these factors is not sufficiently conclusive and requires further research.

Vasodilation is not the only mechanism responsible for the pathological process in HPS patients. In recent studies, inhalation treatment with L-NAME in patients with HPS resulted in a significant decrease of systemic and pulmonary vasodilation, however, their arterial hypoxemia has not improved $[34,55]$. Gomez et al. argue that arterial hypoxemia in patients with HPS is not strictly related to the existing vasodilator effect of NO [56]. It is likely, that vasodilation by itself does not cause more than 10-fold increase in the diameter of capillaries with little smooth muscle in HPS patients.

\section{ENDOTHELIN -1 AND ENDOTHELIN RECEPTORS}

A lot of attention in the investigation of HPS pathogenic mechanisms is paid to endothelin-1 (ET-1), which is formed in the endothelium [24, 57]. Endothelium is a monolayer of epithelial cells lining the inner surface of blood vessels. It produces a large number of biologically active substances, serving as a paracrine organ. The main role of the endothelium is to maintain homeostasis by regulating the balance of opposite processes: vascular tone (vasoconstriction/ vasodilatation), structural building of blood vessels (synthesis/inhibition of proliferation factors), hemostasis (synthesis/inhibition of fibrinolysis factors and platelets aggregation), and local inflammation (production of pro- and anti-inflammatory factors) [43].

Moreover, endothelium synthesises a group of polypeptides, so called endothelins, discovered in 1988 by M. Janagisawa. There are 3 isoforms of endothelin: ET-1, ET-2 and ET-3, differing in the amino acid sequence. Endothelin is synthesised from proendotelin (endothelin
B) under the influence of endotelin converting enzyme. The synthesis of endothelin is increased by thrombin. The action of endothelin is complex and is determined by a number of factors. The most active isomer is ET-1, consisting of 21 amino acids. Its half-life is 10-20 minutes, and in plasma 4-7 minutes. ET-1 acts by binding to receptors $\mathrm{ET}_{\mathrm{A}}, \mathrm{ET}_{\mathrm{B} 1}$ and $\mathrm{ET}_{\mathrm{B} 2} . \mathrm{ET}_{\mathrm{A}}$ and $\mathrm{ET}_{\mathrm{B} 2}$ receptors are localized in vascular smooth muscle. $\mathrm{ET}_{\mathrm{B} 1}$ receptors are localized in endothelium [58].

It may seem improbable that ET-1, a recognized vasoconstrictor, can cause vasodilation of the pulmonary microvascular bed. The local production of ET-1 in response to various stimuli is mostly abluminal and is associated with $\mathrm{ET}_{\mathrm{A}}$ receptors on vascular smooth muscle cells, causing contraction and vasoconstriction. Smaller amount of local peptide is released luminally (into the lumen of blood vessels) causing vasodilation due to increased eNOS activity and $\mathrm{NO}$ production by binding to $\mathrm{ET}_{\mathrm{B}}$ receptors [59].

Hyperproduction of ET-1 occurs in the liver of patients with HPS. Through the tight contact ET-1 enters the circulatory system, binds to ET-receptors in the endothelial cells of the lung vessels, causing increase in the expression and activity of eNOS, and vasodilation [60]. In addition, there is evidence that the introduction of $\mathrm{ET}_{\mathrm{B}}$ receptor selective antagonist to animals after ligation of the common bile duct causes a reduction in pulmonary endothelial eNOS and improvement of HPS symptoms [61].

At the same time, modelling of experimental HPS in $\mathrm{ET}_{\mathrm{B}}$ receptor-deficient rats showed that level of ET-1 in plasma has not increased and HPS did not develop compared to the control group [62]. M. Fallon described the increase in plasma levels of ET-1 within 2 weeks after ligation of the common bile duct in rats. This increase of ET-1 in plasma correlated with increase in pulmonary eNOS, magnitude of intrapulmonary vasodilation and gas exchange indicators [24]. The levels of NO and ET-1 were significantly elevated in plasma, liver and lung homogenate of rats with experimental models of HPS [63]. 
The increased hepatic production and concentration in circulatory system of ET-1 were also detected in other experimental and human liver disorders. However, these concentrations were much lower compared to the outcomes of common bile duct ligation and they were detected only at advanced stages of the disease in the presence of significant hyperdynamic changes and ascites [64, 65].

\section{ANGIOGENESIS}

Recent studies showed that angiogenesis is also an important factor in the pathogenesis of experimental HPS [66, 67]. Physiological angiogenesis is a tissue response to hormonal stimulation or to external changes. Hypoxia is a major stimulus for angiogenesis, affecting metabolic pathways that are regulated by proteins such as hypoxia inducible factor 1 . This leads to overexpression of proangiogenic factors, including vascular endothelial growth factor (VEGF) and fibroblasts growth factors.

VEGF family consists of six growth factors: VEGF-A, VEGF-B, VEGF-C, VEGF-D, VEGF-E, and placental growth factor; VEGF-A being the most exensively studied among them. In human, there 4 isoforms of VEGFA: VEGF-A121, VEGF-A165, VEGF-A189, VEGF-A206, arising from alternative splicing of mRNA. Isoforms have similar biological activity, but significantlyvary in bioavailability, which is determined by the size of molecules and is regulated at genetic level.

VEGF-A acts by binding to appropriate tyrosine kinase receptors VEGFR1 and VEGFR2 and initiating phosphorylation processes. Hypoxia, in turn, increases the expression of both VEGFR1 and VEGFR2 receptors. As the action of proangiogenic factors dominates the action of antiangiogenic (trombospondin-1), endothelial cells transform from the usual "sleeping" to the active state. This tipping point is called the iniciation of angiogenesis." There are 4 main stages of angiogenesis [68]:

1. Proteolytic destruction of the vascular basement membrane and intercellular matrix.

2. Migration of endothelial cells and their colonization of the extravascular space.

3. Proliferation of endothelial cells.

4. Formation of tubular structures, and of the new capillary net.

Urinary activator of plasminogen or urokinase is the main regulator of extracellular proteolysis, triggering the cascade of proteolytic reactions on cell surface which encourages formation and growth of blood vessels. Binding to specific receptors on the cell membrane, urokinase activates plasmin in specific areas on cell surface, which in turn activates matrix metalloproteases, destroying key proteins of extracellular matrix and opening space for cell movement. In addition, proteases activate and release from the matrix the majority of angiogenic factors required for proliferation, migration and invasion of cells. Finally, urokinase, interacting with its receptor and other proteins on the cell surface, modulates intracellular signaling, which ensures directional movement of the cells [69].

Thus, angiogenesis is induced when metabolic requirements exceed the existing capacity of vascular perfusion. This is an adaptive response to the relative lack of oxygen which increases angiogenic stimuli [68]. Thus, the increase in the number of lung capillaries, increased pulmonary accumulation and activation of monocytes, Akt and eNos are all signalling pathways associated with angiogenesis. Introduction of pentoxifylline reduces capillary net and pulmonary accumulation of monocytes, thus regulating pulmonary angiogenic factors and improving the course of HPS [56, 67, 70].

Elevated levels of vascular endothelial growth factor A were found in alveolar macrophages and endothelial cells of blood vessels. In non-biliary cirrhosis induced by tioacetamide, angiogenesis have not been detected, the accumulation of monocytes in the lungs was significantly lower, and Akt, eNos, and vascular endothelial growth factor A were not activated [70].

Liver angiogenesis occurs through VEGFdependent pathways [71]. The expression of 
VEGF-A165, subtype of VEGF-A was confirmed in pathological states, on experimental models of liver cirrhosis. Pulmonary intravascular accumulation of monocytes was low and VEGF-A expression was not significantly increased in cases of non-biliary cirrhosis induced by tioacetamide. This is in contrast to the effects of the common bile duct ligation in rats, where significant accumulation of monocytes, and overexpression of VEGF-A were observed. These effects decreased after the introduction of pentoxifylline, which is known to inhibit the adhesion of mononuclear cells to endothelial. It is argued that monocyte accumulation in the pulmonary microvascular bed can be explained by bacterial translocation and increased production of circulating TNF- $\alpha$. The positive impact of pentoxifylline may be due to its inhibition of TNF- $\alpha$ [62]. However, other studies, found that while the level of circulating TNF- $\alpha$ in liver cirrhosis induced by tioacetamide was significantly elevated, the accumulation of monocytes was minimal and HPS did not develop [35].

Together, these results suggest that other mechanisms are involved in the accumulation of monocytes in the experimental HPS, and this topic requires further investigation.

\section{INTESTINAL ENDOTOXEMIA}

Several authors examined a significant role of intestinal endotoxemia and bacterial translocation in the pathogenesis of HPS [72-75]. Endotoxins are lipopolysaccharides and components of inner monolayer of Gram-negative bacterial membrane [76]. Endotoxin induced activation of monocyte/macrophagal system in vivo involves Kupffer cells, macrophages of spleen, pulmonary intravascular macrophages and blood mononuclear cells [56].

As neutrophils phagocyte bacteria in blood plasma and intercellular space, passing through theepithelial monolayer and endothelium in a process called leukocyte extravasationthey carry with them bacteria. Neutrophils isolate and inactivate bacteria using reactive oxygen species and myeloperoxidase, but is not clear whether they managege to to kill the bacteria. Endosome cells do not posess proteolytic enzymes and cannot lyse bacteria. Thus, neutrophils are involved the emergence of bacterial translocation syndrome [76].

There are three main mechanisms causing bacterial translocation in liver cirrhosis: disruption immune response, change of the bacterial flora in the small intestine and increased intestinal permeability. Currently, the causes of local immunological deficits in the intestinal wall are not completely understood. The increased number of intraepithelial lymphocytes exhibiting significant reduction in their proliferative activity and in g-interferon production in sone such potential cause. The others can be due to insufficient opsonization (casused by insufficient complement synthesis by the affected liver), dysfunction of macrophagal Fc $\gamma$ receptors and reduced phagocytic properties of the neutrophils.

Reduction of motor activity of the small intestine, typical for the cirrhosis patients, promotes excessive bacterial growth syndrome when the total increase of bacteria strains is accompanied by the increase of gram-negative and anaerobic strains. Moreover, intestinal mucosa is damaged by oxidative stress in course of liver cirrhosis, which is manifested as redness, swelling, presence of granulomas, vascular disorders and increases its permeability [77].

Vallance P. and Moncada S. proposed that endotoxemia in liver cirrhosis is caused either directly by the movement of bacteria through the intestinal mucosa or indirectly through the cytokine cascade stimulates vascular endothelial iNOS, which increases the production of $\mathrm{NO}$ [78]. Surface membrane of macrophages located in the lymph nodes of mesentery contains numerous receptors for cytokines, hormones, complement components and $\mathrm{Fc}$-fragments of $\mathrm{IgG}$, as well as a large number of antigens, the most characteristic of which is antigen CD14. It functions as a receptor for lipopolysaccharides of Gram-negative bacteria cell wall. Bacterial 
lipopolysaccharides complex binding to the CD14 antigen $b$ initiates immediate activation of macrophages and starts proinflammatory cytokines synthesis (interleukin1, interleukin 6 , and tumor necrosis factor $-\alpha$ ) [79].

In the lumen of the intestine in physiological conditions Gram-negative bacteria constantly release endotoxins. However, their pathogenic effects are not immediately apparent, since only a small portion of endotoxins from the intestine are absorbed and enter portal circuit to the liver, where they are quickly neutralized by Kupffer cells $[77,80]$.

In liver diseases, especially in hepatic failure, intestinal endotoxemia develops as a substantial amount of endotoxins from the intestine reaches the portal circuit blood or goes directly into the systemic circulation. Thus, Kupffer cells of the liver remove pathogens and their toxins from the portal circulation. As liver cirrhosis develops, blood stasis, swelling of the mucosa, weakened intestinal peristalsis and reduced secretion of bile, lead to bacterial overgrowth in the lumen of the intestine, especially of the Gram-negative bacteria and to overproduction of endotoxins. At the same time, disrupted mucosal barrier and dysfunction in hepatocytes and Kupffer cells cause migration of intestinal organisms and endotoxins into the blood, causing bacteremia and intestinal endotoxemia. Endotoxins destroy mitochondria and lysosomes of intestinal epithelial cells, triggering cell autolysis. Ultimately, a vicious circle of intestinal endotoxemia and increased permeability of intestinal mucosa is created.

Zhang et al. showed significant increase of endotoxin and TNF- $\alpha$ levels in plasma and increased number of Gram-negative microorganism colonies in rats with HPS, which suggests that intestinal endotoxemia is indeed implicated in the pathogenesis of experimental HPS [75]. The conclusions of this study are consistent with previous findings that infections aggravate the condition of patients with chronic liver disease [81]. Increased production of $\mathrm{TNF}-\alpha$ can also result from hypoxemia. $\mathrm{TNF}-\alpha$ plays a role in the damage of the intestinal barrier that results in intestinal endotoxemia and bacteremia. Subsequently, intestinal endotoxemia can cause intrapulmonary vasodilation and hypoxia. Hypoxemia can exacerbate intestinal barrier damage due to release of a number of cytokines (including TNF- $\alpha$ ). Thus, a «vicious circle» develops in which hypoxemia and impaired barrier function of the intestinal mucosa intensifies each other [75].

Bile acids have bacteriostatic effect on the intestinal flora. In liver cirrhosis their secretion is reduced, causing excessive bacterial growth. As a result of microorganism activity in small intestine, the concentration of unconjugated bile acids increases. It damages mucosa epithelium causing inactivation of glycoproteins in apical membrane of brush border microvilliand increase mucosa epithelium permeability [77].

Patients with liver cirrhosis present high concentrations of nitrites and nitrates in plasma, urine and ascitic fluid. Excessive production of NO reduces activity of protein kinase and RhoA kinase, disrupting actin polymerization and myosin phosphorylization. This reduces sensitivity of vascular smooth muscle to vasoconstrictors in the bloodstream [77].

The summary of molecular alterations in the pulmonary microcirculation in experimental hepatopulmonary syndrome is shown below (fig.1):

\section{GENETIC RISK FACTORS}

Determining genetic risk factors can point to new HPS pathogenetic links and therapeutic approaches. Roberts et al. selected 94 genes that affect vascular function and genotyped 1086 single nucleotide polymorphisms (SNP). Their results showed that 42 SNPs were associated with HPS. 32 of them were grouped in eight genes: caveolin 3 (CAV3), endoglin (ENG), NADPH oxidase (NOX4), estrogen receptor 2 (ESR2), von Willebrand factor (VWF), short-bound transcription factor 1 (RUNX1), collagen type XVIII, $\alpha 1$ (COL18A1), and tyrosine (TIE1). 
This is consistent with experimental data, demonstrating the important role of pulmonary angiogenesis in the pathogenesis of HPS $[82,83]$.

In contrast, no connection was found between HPS and vasoregulator genes, such as nitrogen (II) oxide, endothelin B receptor, heme-oxygenase, which were initially suggested to be linked to the development of the HPS. In addition, a number of genetic risk factors regulating angiogenesis were identified for HPS, including. endostatyn, proteolytic fragment of COL18A1 C-terminus, which inhibits angiogenesis [84].

Endoglin is a transmembrane receptor for transforming growth factor beta (TGF- $\beta$ ), which is mainly expressed on proliferating endothelial cells. Mutations in endoglin and
TGF- $\beta$ are linked with hereditary hemorrhagic telangiectasia, an autosomal dominant vascular dysplasia, characterized by telangiectasia and arteriovenous connections [85]. Notably, among the patients with hereditary hemorrhagic telangiectasia, pulmonary arteriovenous connections are more common in those individuals that have endoglin mutations [86].

Hypoxemia is a powerful stimulator of vascular growth and remodeling, and in pulmonary vessels, oxygen level is crucial for mantaining normal gas exchange through the corrections of vascular tone. Four genes, HIFA1, SAT2, RUNX1, and NOX4, play a central role in oxygen-dependent vascular phenotypes. HIF1A stimulates angiogenesis of endothelial cells in hypoxia through the activation of the numerous

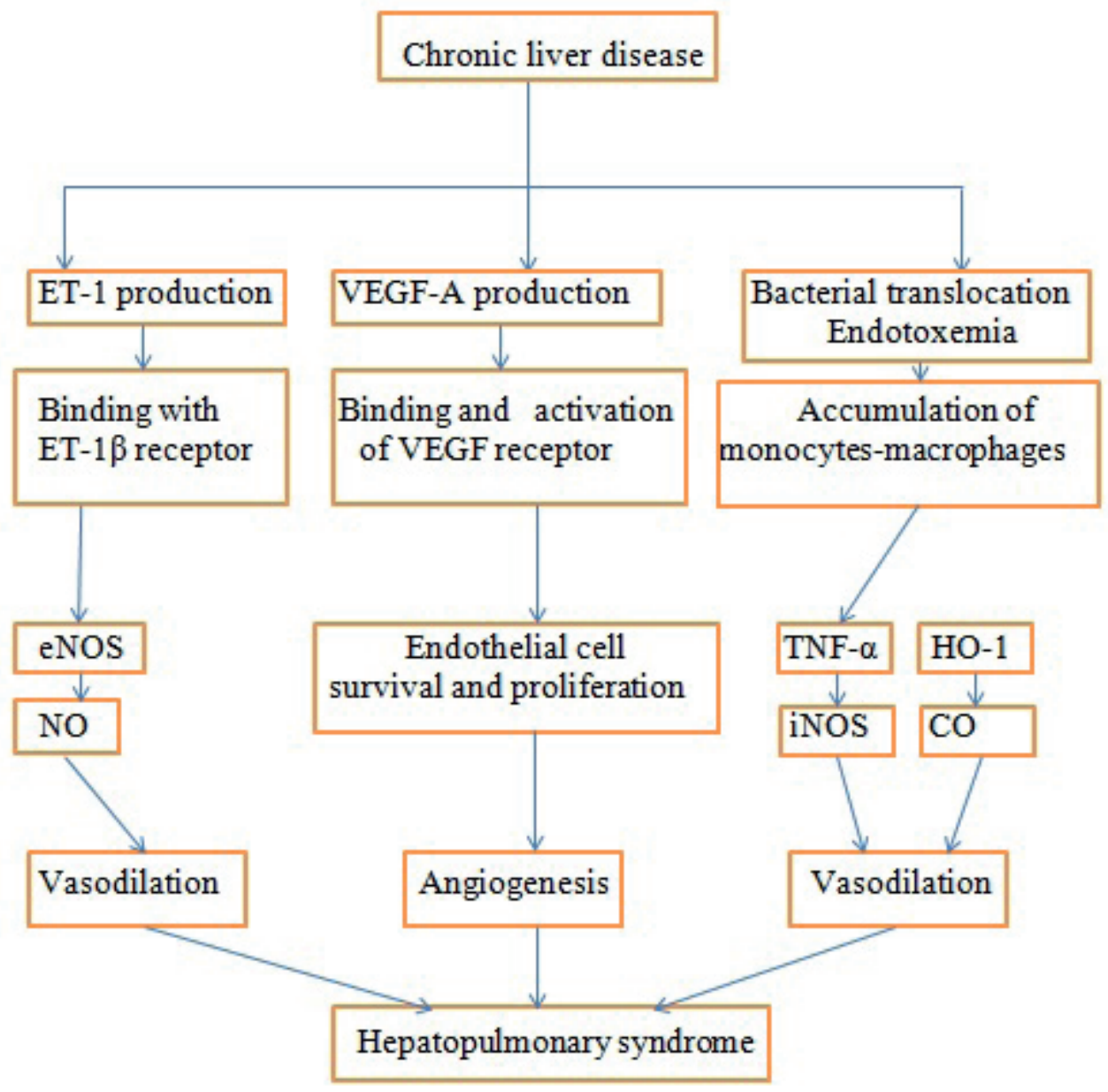

Molecular alterations in the pulmonary microcirculation in experimental hepatopulmonary syndrome 
growth factors transcription and is regulated by SAT2 [87]. Variations in both genes are associated with HPS. RUNX1 is a hematopoietic transcription factor that promotes angiogenic phenotype through the interaction with other transcription factors, such as HIF1 A and insulin growth factor binding protein 3 [57]. NOX4 is one of the enzymes responsible for the generation of reactive oxygen species in endothelial cells, which model angiogenesis and are involved in hypoxic-induced proliferation [88]. These results show changes in specific genes that may contribute to susceptibility to HPS.

In summary, hepatopulmonary syndrome is a severe pulmonary vascular complication of liver disease. It remains a captivating topic of research, since the syndrome significantly affects both quality of life and survival in the patients with chronic liver disease with or without underlying portal hypertension. Currently, pathogenesis of HPS is not completely explained, and there is no effective pharmacological treatment with orthotopic liver transplantation being the only successful treatment method. While our understanding of the mechanisms of the pulmonary vasodilation that underlies the condition continues to improve, it has yet to translate in the development of effective pharmacological therapy. Future research should address the genetic polymorphisms associated with the hepatopulmonary syndrome, circulating factors emanating from the hepatic veins that may affect the pulmonary vascular tone, and angiogenic factors.

\section{И.Я. Криницкая, М.И. Марущак, И.Н. Клищ, И.В. Бирченко \\ МОЛЕКУЛЯРНЫЕ МЕХАНИЗМЫ РАЗВИТИЯ ГЕПАТОПУЛЬМОНАЛЬНОГО СИНДРОМА}

Гепатопульмональный синдром (ГПС) является серьезным осложнением хронических заболеваний печени. Его распространенность среди пациентов с циррозом колеблется от 4 до 47 \%. Патогенетические звенья ГПС остаются неизвестными. В этом обзоре мы кратко суммировали существующие знания о возможных механизмах и причинах ГПС. Легочная микрососудистая дилатация и ангиогенез являются двумя центральными звеньями, которые опреде- ляют патологический газообмен при экспериментальном ГПС, и, таким образом, могут быть основой ГПС в организме человека. Несмотря на эти достижения в патогенезе экспериментального ГПС, его медикаментозной терапии не существует, и трансплантация печени остается основным методом лечения.

Ключевые слова: гепатопульмональный синдром; молекулярные механизмы.

ГВУЗ «Тернопольский государственный медицинский университет имени И.Я. Горбачевского МОЗ Украины»

\section{І.Я. Криницька, М.І. Марущак, І.М. Кліщ, І.В. Бірченко}

\section{МОЛЕКУЛЯРНІ МЕХАНІЗМИ РОЗВИТКУ ГЕПАТОПУЛЬМОНАЛЬНОГО СИНДРОМУ}

Гепатопульмональний синдром (ГПС) є серйозним ускладненням хронічних захворювань печінки. Його поширеність серед пацієнтів з цирозом коливається від 4 до 47 \%. Патогенетичні ланки ГПС залишаються невідомими. У цьому огляді ми коротко підсумували існуючі знання про можливі механізми і причини ГПС. Легенева мікросудинна дилатація і ангіогенез $є$ двома центральними ланками, які визначають патологічний газообмін при експериментальному ГПС, i, таким чином, можуть бути основою ГПС в організмі людини. Незважаючи на ці досягнення в патогенезі експериментального ГПС, його медикаментозної терапії не існує, і трансплантація печінки залишається основним методом лікування.

Ключові слова: гепатопульмональний синдром; молекулярні механізми.

ДВНЗ «Тернопільський державний медичний університет імені І.Я. Горбачевського МОЗ України»

\section{REFERENCES}

1. Fluckiger M. Vorkommen von trommelschagel formigen fingerendphalangen ohne chronische veranderungen an der lungen oder am herzen. Wien Med Wochenschr. 1884; 34:1457-61.

2. Amin Z, Amin HZ, Tedyanto NM. Hepatopulmonary syndrome: a brief review. Romanian Journal of Internal Medicine. 2016; 54(2):93-7.

3. Grace JA, Angus PW. Hepatopulmonary syndrome: update on recent advances in pathophysiology, investigation, and treatment. J Gastroenterol Hepatol. 2013; 28(2):213-19.

4. Rodriguez-Roizin R, Krowka MJ. Hepatopulmonary syndrome - a liver-induced lung vascular disorder. New England Journal of Medicine. 2008; 358:2378-87.

5. Zhang J, Fallon MB. Hepatopulmonary syndrome: update on pathogenesis and clinical features. Nat Rev Gastroenterol Hepatol. 2012; 9(9):539-49.

6. Lima B, Martinelli AA, Franca V. Hepatopulmonary syndrome: pathogenesis, diagnosis and treatment. Arq Gastroenterol. 2004; 41(4):250-58. 
7. Goncalves de Macedo L, Pessoa de Almeida Lopes E. Hepatopulmonary syndrome: an update. Sao Paulo Med J. 2009; 127(4):223-30.

8. Gorgy AI, Jonassaint NL, Stanley SE, Koteish A, DeZern AE, Walter JE, Sopha SC, Hamilton JP, Hoover-Fong J, Chen AR, Anders RA, Kamel IR, Armanios M. Hepatopulmonary syndrome is a frequent cause of dyspnea in the short telomere disorders. Chest. 2015; 148:1019.

9. Shafiq M, Khan AA, Alam A, Coll J. Frequency of hepatopulmonary syndrome in cirrhotic patients. Physician Surq Рак. 2008; 18(5):278-81.

10. Borkar VV, Poddar U, Kapoor A, Srivastava A, Yachha SK. Hepatopulmonary Syndrome in children: a comparative study of non-cirrhotic vs. cirrhotic portal hypertension. Liver International. 2015; 35(6):1665-72.

11. Cosarderelioglu C, Cosar AM, Gurakar M, Dagher NN, Gurakar A. Hepatopulmonary Syndrome and Liver Transplantation: A Recent Review of the Literature. Journal of Clinical and Translational Hepatology. 2016; 4(1):47.

12. Zhang Z, Qi X, Li Z, Xu L, Wang F, Wang S, Chang Y, Ma W, Xu M, Yang C. Hepatopulmonary syndrome: the role of intra-abdominal hypertension and a novel mouse model. Int J Clin Exp Pathol. 2014; 7(2):768-73.

13. Espinosa MD, Nogueras F, Olmedo C, Macias R, Muffak-Granero K, Comino A, Villegas T, Ramirez JA, De Teresa J, Garrote D, Bueno P. Hepatopulmonary syndrome among cirrhotic candidates for liver transplantation. Transplantation Proceedings. 2012; 44(6):1508-9.

14. Krowka MJ. Management of pulmonary complications in pretransplant patients. Clin Liver Dis. 2011; 15(4):765-77.

15. Machicao VI, Fallon MB. Hepatopulmonary syndrome. Semin Respi. Cri Care Med. 2012; 33(1):11-6.

16. Younis I, Sarwar S, Butt Z, Tanveer S, Qaadir A, Jadoon NA. Clinical characteristics, predictors, and survival among patients with hepatopulmonary syndrome. Ann Hepatol. 2015; 14:354.

17. Taille C, Cadranel J, Bellocq A. Liver transplantation for hepatopulmonary syndrome: a ten-year experience in Paris, France. Transplantation. 2003; 75(9):1482-89.

18. Nayyar D, Man HS, Granton J, Lilly LB, Gupta S. Proposed management algorithm for severe hypoxemia after liver transplantation in the hepatopulmonary syndrome. Am J Transplant. 2015; 15(4):903-13.

19. Dziedziczko A, Bartuzi Z. Hepatopulmonary syndromeknown symptoms and new name. Case Rep. Clin Pract Rev. 2002; (3):121-7.

20. Dinh-Xuan AT, Naeije R. The hepatopulmonary syndrome: NO way out? European Respiratory Journal. 2004; 23(5):661-2.

21. Kalinichenko OV, Myshunina TM, Tron'ko MD. Nitric oxide synthase activity and its concentration in the tissues of human thyroid carcinomas. Fiziol Zh. 2016; 62(3):9-19. [Ukrainian].

22. Strutynska NA, Kotsiuruba AV, Budko AYu, Mys LA, Sagach VF. Mitochondrial dysfunction in the aging heart is accompanied by constitutive no-synthases uncoupling on the background of oxidative and nitrosative stress. Fiziol Zh. 2016; 62(2):3-11. [Ukrainian].

23. Förstermann U, Sessa WC. Nitric oxide synthases: regulation and function. European Heart Journal. 2012; 33(7):829-37.

24. Fallon MB. Mechanisms of pulmonary vascular complications of liver disease: hepatopulmonary syndrome. Journal of Clinical Gastroenterology. 2005; 39(4):S138-42.

25. Hamamoto J, Toba S, Hirosako S, Nakamura K, Fujii K, Kohrogi H. A case of hepatopulmonary syndrome with elevated exhaled nitric oxide. Nihon Kokyuki Gakkai Zasshi. 2010; 48(5):379-84.

26. Rolla G, Brussino L, Colagrande P. Exhaled nitric oxide and impaired oxygenation in cirrhotic patients before and after liver transplantation. Ann Intern Med. 1998; 129(5):375-78.

27. Degano B, Mittaine M, Hervé P, Rami J, Kamar N, Suc $\mathrm{B}$, Rivière $\mathrm{D}$, Rostaing L. Nitric oxide production by the alveolar compartment of the lungs in cirrhotic patients. European Respiratory Journal. 2009; 34(1):138-44.

28. Delclaux C, Mahut B, Zerah-Lancner F, Delacourt C, Laoud S, Cherqui D, Duvoux C, Mallat A, Harf A. Increased nitric oxide output from alveolar origin during liver cirrhosis versus bronchial source during asthma. American Journal of Respiratory and Critical Care Medicine. $2002 ; 165(3): 332-7$.

29. Nunes H, Lebrec D, Mazmanian M, Capron F, Heller J, Tazi KA, Zerbib E, Dulmet E, Moreau R, Dinh-Xuan AT, Simonneau G, Hervé P. Role of nitric oxide in hepatopulmonary syndrome in cirrhotic rats. Am J Respir Crit Care Med. 2001; 164(5):879-85.

30. Zhang J, Ling Y, Luo B, Tang L, Ryter SW, Stockard CR, Grizzle WE, Fallon MB. Analysis of pulmonary heme oxygenase-1 and nitric oxide synthase alterations in experimental hepatopulmonary syndrome. Gastroenterology. 2003; 125:1441-51.

31. Brussino L, Bucca C, Morello M, Scappaticci E, Mauro M, Rolla G. Effect on dyspnoea and hypoxaemia of inhaled N G-nitro-L-arginine methyl ester in hepatopulmonary syndrome. The Lancet. 2003; 362(9377):43-4.

32. Aksu B, Umit H, Kanter M, Guzel A, Aktas C, Civelek S, Uzun H. Effects of methylene blue in reducing cholestatic oxidative stress and hepatic damage after bile-duct ligation in rats. Acta Histochemica. 2010; 112(3):259-69.

33. Schenk P, Madl C, Rezaie-Majd S, Lehr S, Müller C. Methylene blue improves the hepatopulmonary syndrome. Ann Intern Med. 2000; 133(9):701-6.

34. Gómez FP, Barberà JA, Roca J, Burgos F, Gistau C, Rodríguez-Roisin R. Effects of nebulized NG-nitro-Larginine methyl ester in patients with hepatopulmonary syndrome. Hepatology. 2006; 43(5):1084-91.

35. Luo B, Liu L, Tang L, Zhang J, Ling Y, Fallon MB. Et-1 and TNF-alpha in HPS: analysis in prehepatic portal hypertension and biliary and nonbiliary cirrhosis in rats. Am J Physiol Gastrointest Liver Physiol. 2004; 286(2):G294-G303.

36. Liu L, Liu N, Zhao Z, Liu J, Feng Y, Jiang H, Han 
D. TNF- $\alpha$ neutralization improves experimental hepatopulmonary syndrome in rats. Liver International. 2012; 32(6):1018-26.

37. Olmos G, Lladó J. Tumor Necrosis Factor Alpha: A Link between Neuroinflammation and Excitotoxicity. Mediators of Inflammation [serial on the Internet]. 2014 May [cited 2016 Sept 21];2014:[about 12 p.]. Available from: https://www.hindawi.com/journals/ $\mathrm{mi} / 2014 / 861231 / \mathrm{cta} /$

38. Panasyukova OR, Kadan LP. The role of inflammatory mediators in the pathogenesis of COPD (Literature Review). Ukr Chemioter J. 2009; (3):15-20. [Ukrainian].

39. Prokhorenko TS, Saprina TV, Lazarenko FE, Ryazantseva NV, Vorozhtsova IN, Novitsky VV. The system of tumor necrosis factor $\alpha$ in the pathogenesis of autoimmune diabetes mellitus. Bulletin of Siberian Medicine. 2011; 10(1):64-9. [Russian].

40. Sztrymf B, Rabiller A, Nunes H, Savale L, Lebrec D, Le Pape A, de Montpreville V, Mazmanian M, Humbert M, Hervé P. Prevention of hepatopulmonary syndrome and hyperdynamic state by pentoxifylline in cirrhotic rats. Eur Respir J. 2004; 23(5):752-58.

41. Garbuzenko DV. The pathophysiological mechanisms and new areas of treatment of portal hypertension in liver cirrhosis. Clin Perspectives of Gastroenterol, Gepatol. 2010; (6):11-20. [Russian].

42. Van Landeghem L, Laleman W, Vander EI, Zeegers M, van Pelt J, Cassiman D, Nevens F. Carbon monoxide produced by intrasinusoidally located haemoxygenase -1 regulates the vascular tone in cirrhotic rat liver. Liver Int. 2009; 29(5):650-60.

43. Félétou M. The endothelium. Part I: Multiple functions of the endothelial cells-focus on endothelium-derived vasoactive mediators. In Colloquium Series on Integrated Systems Physiology: From Molecule to Function. 2011; 3(4):1-306.

44. Nechyporuk VM, Korda MM. Modern aspects of metabolism of sulfur-containing amino acids. Med Chemistry. 2010; (12):126-32. [Ukrainian].

45. Drachuk KO, Dorofeyeva NA, Sagach VF. The role of hydrogen sulfide in diastolic function restoration during aging. Fiziol Zh. 2016; 62(6):9-18.

46. Yanchuk PI, Slobodianyk LA. The role of hydrogen sulfide in regulation of circulation blood liver. Fiziol Zh. 2015; 61(3):28-34. [Ukrainian].

47. Li L, Bhatia M, Moore PK. Hydrogen sulphide - a novel mediator of inflammation? Curr Opin Pharmacol. 2006; $6(2): 125-9$.

48. Waqner CA. Hydrogen sulfide: a new gaseous signal molecule and blood pressure regulator. J Nephrol. 2009; 2(22):173-76.

49. Atucha NM, Ortíz MC, Fortepiani LA, Nadal FJ, Martínez-Prieto C, García-Estañ J. Mesenteric hyporesponsiveness in cirrhotic rats with ascites: role of cGMP and $\mathrm{K}+$ channels. Clinical Science. 2000; 99(5):455-60.

50. Hennenberg M, Trebicka J, Sauerbruch T, Heller J. Mechanisms of extrahepatic vasodilation in portal hypertension. Gut. 2008; 57(9):1300-14.

51. Hennenberg M, Biecker E, Trebicka J, Jochem K, Zhou Q, Schmidt M, Jakobs KH, Sauerbruch T, Heller J. Defective RhoA/Rho-kinase signaling contributes to vascular hypocontractility and vasodilatation in cirrhotic rats. Gastroenterology. 2006; 130(2):838-54.

52. Hennenberg M, Trebicka J, Biecker E. Vascular dysfunction in human and rat cirrhosis: role of receptor-desensitizing and calcium-sensitizing proteins. Hepatology. 2007; 45(2):495-506.

53. Castro A, Jiménez W, Clária J, Ros J, Martínez JM, Bosch M, Arroyo V, Piulats J, River F, Rodés J. Impaired responsiveness to angiotensin II in experimental cirrhosis: role of nitric oxide. Hepatology. 1993; 18(2):367-72.

54. Chang SW, Ohara N. Pulmonary circulatory dysfunction in rats with biliary cirrhosis. Am Rev Respir Dis. 1992; 148:798-805.

55. Ho V. Current concepts in the management of hepatopulmonary syndrome. Vascular Health and Risk Management. 2008; 4(5):1035-41.

56. Gill SS, Suri SS, Janardhan KS, Caldwell S, Duke T, Singh B. Role of pulmonary intravascular macrophages in endotoxin-induced lung inflammation and mortality in a rat model. Respiratory Research. 2008; 9(1):1.

57. Iwatsuki K, Tanaka K, Kaneko T, Kazama R, Okamoto S, Nakayama Y, Ito Y, Satake M, Takahashi S, Miyajima A, Watanabe T, Hara T. Runx1 promotes angiogenesis by down-regulation of insulin-like growth factor-binding protein-3. Oncogene. 2005; 24(7):1129-37.

58. Reichetzeder C, Tsuprykov O, Hocher B. Endothelin receptor antagonists in clinical research - Lessons learned from preclinical and clinical kidney studies. Life Sciences. 2014; 118(2):141-48.

59. Zhang ZJ, Chang-Qing Y. Progress in investigating the pathogenesis of hepatopulmonary syndrome. Hepatobiliary Pancreat Dis Int. 2010; 9(4):355-60.

60. Vercelino R, Tieppo J, Forgiarini Junior LA, Dias AS, Marroni CA, Marroni NP. Experimental models for assessment of pulmonary alterations in hepatopulmonary syndrome. J Bras Pneumol. 2008; 34(7):453-60.

61. Ling Y, Zhang J, Luo B, Song D, Liu L, Tang L, Stockard CR, Grizzle WE, Ku DD, Fallon MB. The role of endothelin-1 and the endothelin B receptor in the pathogenesis of hepatopulmonary syndrome in the rat. Hepatology. 2004; 39(6):1593-1602.

62. Zhang J, Ling Y, Tang L, Luo B, Pollock DM, Fallon MB. Attenuation of experimental hepatopulmonary syndrome in endothelin B receptor-deficient rats. Am J Phisiol Gastrointest Liver Physiol. 2009; 296(4):G704-G708.

63. Yan Y, Bao XQ, Wang Y. Roles of vascular mediators in the pathogenesis of hepatopulmonary syndrome in rats. Shijie Huaren Xiaohua Zazhi. 2008; 16:1053-58.

64. Luo B, Abrams GA, Fallon MB. Endothelin-1 in the rat bile duct ligation model of hepatopulmonary syndrome: correlation with pulmonary dysfunction. J Hepatology. 1998; 29(4):571-78.

65. Pinzani M, Milani S, De Franco R, Grappone C, Caligiuri 
A, Gentilini A, Tosti-Guerra C, Maggi M, Failli P, Ruocco C, Gentilini P. Endothelin 1 is overexpressed in human cirrhotic liver and exerts multiple effects on activated hepatic stellate cells. Gastroenterology. 1996; 110(2):534-48.

66. Silva HM, Reis G, Guedes M, Cleto E, Vizcaíno JR, Kelly D, Gennery AR, Silva ES. A case of hepatopulmonary syndrome solved by mycophenolate mofetil (an inhibitor of angiogenesis and nitric oxide production). J Hepatol. 2013; 58(3):630-33.

67. Zhang J, Luo B, Tang L, Wang Y, Stockard CR, Kadish I, Van Groen T, Grizzle WE, Ponnazhagan S, Fallon MB. Pulmonary angiogenesis in a rat model of hepatopulmonary syndrome. Gastroenterology. 2009; 136(3):1070-80.

68. Sprindzhuk MV. Angiogenesis. Annals of Restorative Medicine. 2010; (5):15-20. [Russian].

69. Tsokolaeva ZI. Stimulation of angiogenesis in ischemic myocardium and skeletal muscles by transient transgenic expression of urokinase [disertation], Moscow; 2006. [Russian].

70. Fallon MB, Abrams GA, McGrath JW, Hou Z, Luo B. Common bile duct ligation in the rat: a model of intrapulmonary vasodilatation and hepatopulmonary syndrome. Am J Physiol Gastrointest Liver Physiol. 1997; 272(4):G779-84.

71. Bosch J. Vascular deterioration in cirrhosis: the big picture. Journal of Clinical Gastroenterology. 2007; 41:S247-53.

72. Neugebauer H, Hartmann P, Krenn S, Glück T, Schölmerich J, Straub R, Wiest R. Bacterial translocation increases phagocytic activity of polymorphonuclear leucocytes in portal hypertension: priming independent of liver cirrhosis. Liver Int. 2008; 28(8):1149-57.

73. Seo YS, Shah VH. The role of gut-liver axis in the pathogenesis of liver cirrhosis and portal hypertension. Clin Mol Hepatol. 2012; 18(4):337-46.

74. Sztrymf B, Libert JM, Mougeot C, Lebrec D, Mazmanian M, Humbert M, Herve P. Cirrhotic rats with bacterial translocation have higher incidence and severity of hepatopulmonary syndrome. J Gastroenterol Hepatol. 2005; 20(10): 1538-44.

75. Zhang HY, Han DW, Su AR, Zhang LT, Zhao ZF, Ji JQ, Li $\mathrm{BH}, \mathrm{Ji}$ C. Intestinal endotoxemia plays a central role in development of hepatopulmonary syndrome in a cirrhotic rat model induced by multiple pathogenic factors. World J Gastroenterol. 2007; 13(47):6385-95.

76. Titov VN, Dugin SF. Translocation syndrome, bacterial lipopolysaccharide, inflammation disorders of biological reactions and blood pressure. Clin Lab Diagn. 2010; (4):21-37. [Russian].
77. Garbuzenko DV. The role of intestine microflora in the development of portal hypertension in hepatic cirrhosis. Clin Medicine. 2007; (8):15-9. [Russian].

78. Vallance P, Moncada S. Hypothesis: induction of nitric oxide synthase in the vasculature underlies the hyperdynamic circulation of cirrhosis. Lancet. 1991; 337:776-78.

79. Micurov AA, Garbuzenko DV. The comparative analysis of level endotoxemia at patients of the cirrhosis of the liver with the portal hypertensia. Fundamental Reseach. 2011; (6):126-8. [Russian].

80. Gehring S, Dickson EM, San Martin ME, van Rooijen N, Papa EF, Harty MW, Tracy TF, Gregory SH. Kupffer cells abrogate cholestatic liver injury in mice. Gastroenterology. 2006; 130(3):810-22.

81. Teuber G, Teupe C, Dietrich CF. Pulmonary dysfunction in non-cirrhotic patients with chronic viral hepatitis. Eur J Intern Med. 2002; 13(5):311-18.

82. O'Grady J. Hepatopulmonary Syndrome: Is It Naïve or Enlightening When Genetic Associations Match Clinical Perspective? Gastroenterology. 2010; 139(1):20-2.

83. Roberts KE, Kawut SM, Krowka MJ, Brown RS, Trotter JF, Shah V, Peter I, Tighiouart H, Mitra N, Handorf E, Knowles JA, Zacks S, Fallon MB. Genetic risk factors for hepatopulmonary syndrome in patients with advanced liver disease. Gastroenterology. 2010; 139(1):130-39.

84. Digtyar AV, Pozdnyakova NV, Feldman NB, Lutsenko SV, Severin SE. Endostatin: current concepts about its biological role and mechanisms of action. Biochemistry (Moscow). 2007; 72(3):235-46.

85. McAllister KA, Grogg KM, Johnson DW. Endoglin, a TGF-beta binding protein of endothelial cells, is the gene for hereditary haemorrhagic telangiectasia type 1 . Nat Genet. 1994;8(4):345-51.

86. Sabbà C, Pasculli G, Lenato GM, Suppressa P, Lastella P, Memeo M, Dicuonzo F, Guant G. Hereditary hemorrhagic telangiectasia: clinical features in ENG and ALK1 mutation carriers. J Thromb Haemost. 2007; 5(6):1149-57.

87. Manalo DJ, Rowan A, Lavoie T, Natarajan L, Kelly BD, Ye SQ, Garcia JG, Semenza GL. Transcriptional regulation of vascular endothelial cell responses to hypoxia by HIF-1. Blood. 2005; 105(2):659-69.

88. Ismail S, Sturrock A, Wu P, Cahill B, Norman K, Huecksteadt T, Sanders K, Kennedy T, Hoidal J. NOX4 mediates hypoxia-induced proliferation of human pulmonary artery smooth muscle cells: the role of autocrine production of transforming growth factor- $\beta 1$ and insulinlike growth factor binding protein-3. Am J Physiol Lung Cell Mol Physiol. 2009; 296(3):L489-L499. 